\title{
HUBUNGAN ANTARA KOMPETENSI PEDAGOGIK GURU AGAMA DENGAN MOTIVASI DAN PRESTASI BELAJAR SISWA DI SMP PGRI 1 CIBINONG
}

\author{
Oleh: Masruro \\ Guru Agama Islam pada Kantor Kementerian Agama Kabupaten Bogor
}

\begin{abstract}
This study used the descriptive analytic method with the survey technique, which took place in May and June 2012 at SMP (Junior High School) PGRI 1 Cibinong, Bogor District. This study population was students of grade VIII of SMP PGRI 1 Cibinong, Bogor District, amounting to 426 students. Samples taken were $20 \%$ of the population numbered 86 students, using the proportional sampling cluster technique. From the results of correlation analysis using the Kendall Tau-b formula, it is shown that most teacher pedagogical competence variables $(X)$, which include sub-variables of mastery of learning theory and principles of educating $\left(X_{1}\right)$, ability to conduct educational learning $\left(X_{3}\right)$, ability to facilitate potential development of students $\left(X_{4}\right)$, ability to communicate effectively, empathetically and politely with students $\left(X_{5}\right)$, and ability to conduct assessment and evaluation process and learning outcomes $\left(X_{6}\right)$, are significantly correlated with the students' motivation variables $\left(Y_{1}\right)$. Only one sub-variable, namely the implementation of curriculum development PAI $\left(X_{2}\right)$, is not significantly correlated positively with students' learning motivation $\left(Y_{1}\right)$. Teacher pedagogical competence $(X)$ is not significantly associated with student achievement in general positively $\left(Y_{2}\right)$, but significantly correlated with learning achievement sub-variable, namely as the formative achievement $\left(Y_{2.1}\right)$.
\end{abstract}

Keywords: Pedagogical competence, learning motivation, student learning achievement

\section{Abstrak}

Penelitian ini menggunakan metode deskriptif analitik dengan teknik survai yang berlangsung pada bulan Mei sampai Juni 2012 di SMP PGRI 1 Cibinong, Kabupaten Bogor. Populasi penelitian ini adalah siswa kelas VIII SMP PGRI 1 Cibinong, Kabupaten Bogor yang semuanya berjumlah 426 orang. Sampel diambil sebanyak $20 \%$ dari populasi sehingga terdapat 86 orang dengan menggunakan teknik cluster proportional sampling. Dari hasil analisis korelasi menggunakan rumus Tau-b Kendall menunjukkan sebagian besar variabel kompetensi pedagogik guru (X) yang meliputi sub variabel pe$n g u a s a a n$ teori belajar dan prinsip-prinsip mendidik $\left(X_{1}\right)$, kemampuan menyelenggarakan pembelajaran yang mendidik $\left(X_{3}\right)$, kemampuan memfasilitasi pengembangan potensi peserta didik $\left(X_{4}\right)$, kemampuan berkomunikasi efektif, empatik dan santun dengan peserta didik $\left(X_{5}\right)$, dan kemampuan menyelenggarakan penilaian dan evaluasi proses dan hasil belajar $\left(X_{6}\right)$ berhubungan nyata dengan variabel motivasi belajar siswa $\left(Y_{1}\right)$. Hanya satu sub variabel, yaitu implementasi pengembangan kurikulum PAI $\left(X_{2}\right)$ yang tidak berhubungan nyata positif dengan motivasi belajar siswa $\left(Y_{1}\right)$. Kompetensi pedagogik guru (X) tidak berhubungan secara nyata positif dengan prestasi belajar siswa secara umum $\left(Y_{2}\right)$, namun berhubungan nyata positif dengan sub variabel prestasi belajar yaitu prestasi formatif $\left(Y_{2.1}\right)$.

Kata Kunci: Kompetensi pedagogik, Motivasi belajar, Prestasi belajar siswa

Naskah diterima 24 Mei 2012. Revisi pertama,10 juni 2012. Revisi kedua, 25 Juni 2012 dan revisi terakhir 7 Juli 2012 


\section{PENDAHULUAN}

\section{Latar Belakang}

Proses pendidikan tidak hanya sekedar mempersiapkan peserta didik untuk mampu hidup dalam masyarakat masa sekarang, tetapi juga untuk hidup dalam masyarakat di masa yang akan datang yang semakin lama semakin sulit diprediksi karakteristiknya. Sehingga menyiapkan generasi yang memiliki resistensi tinggi, dan kompeten untuk dapat berkompetisi, merupakan pekerjaan rumah yang sangat berat bagi sekolah sebagai produsen sumber daya manusia.

Di tengah-tengah kepercayaan bangsabangsa besar di dunia terhadap kekuatan pendidikan dalam memajukan suatu bangsa, mutu pendidikan Indonesia saat ini, dinilai Sukmadinata belum seperti yang diharapkan. Ini disebabkan karena kurangnya sarana prasarana dan figur (guru belum bekerja dengan sungguh-sungguh dan kemampuan profesional guru masih kurang-rendahnya kualitas, kualifikasi dan kompetensi guru $)^{1}$. Indikator mutu pendidikan yang masih jauh dari harapan, terlihat dari banyaknya guru yang belum memenuhi standar kompetensi. Ini tampak dalam beberapa kenyataan di lapangan, antara lain: 1) Guru tidak memiliki pengetahuan dan keterampilan mengelola peserta didik, 2) Kepribadian guru masih labil, ditunjukan dengan banyaknya kasuskasus penyimpangan yang dilakukan oleh oknum guru, 3) Kemampuan pendidik sebagai anggota masyarakat masih rendah, 4) Penguasaan guru terhadap materi pelajaran masih dangkal. ${ }^{2}$

Berkenaan dengan kondisi pendidikan agama secara khusus memiliki problematika tersendiri berupa: 1) Pendidikan agama sebatas formalitas, 2) Lemahnya kualitas

${ }^{1}$ Jejen Musfah. 2011 Peningkatan Kompetensi Guru: Melalui Pelatihan dan Sumber Belajar Teori dan Praktik. Jakarta: Kencana, cet. ke- 1, h. 4

${ }^{2}$ Ibid., h. 7 pendidik, 3) Penanaman sikap beragama di sekolah belum terintegrasi. ${ }^{3}$

Belum lagi di lihat dari sisi siswa masih banyak yang kurang bersemangat dan bersungguh-sungguh dalam aktivitas pembelajarannya, kurang tekun dalam mengerjakan tugas-tugas yang diberikan guru-bahkan banyak yang tidak mengerjakan, dan sering ingin 'instan' saja dengan melihat pekerjaan temannya tanpa perlu kerja keras. Indikasi di atas sebagaimana dikatakan Syahatah merupakan gejala rendahnya motivasi belajar yang terlihat pada beberapa perilaku seperti ; cenderung menjauhi buku, malas berangkat ke sekolah, memilih tidak datang ke sekolah ataupun malas belajar ${ }^{4}$.

Sementara itu berkaitan dengan capaian prestasi belajar siswa di SMP PGRI 1 Cibinong senyatanya belum memperoleh hasil yang optimal. Ini ditunjukan dari nilai UAS PAI tahun terakhir (di ambil kelas VIII, semester genap TP. 2009/ 2010), baru $45 \%$ siswa yang berhasil mencapai KKM (69) dan sisanya sekitar $55 \%$ dinyatakan belum berhasil.

Di sinilah diperlukan peran berbagai stakeholders pendidikan untuk meningkatkan motivasi dan prestasi belajar peserta didik tersebut. Salah satu hal yang diduga dapat meningkatkan motivasi dan prestasi belajar adalah kompetensi pedagogik guru. Kompetensi pedagogik sebagai bagian dari kompetensi yang harus dimiliki guru menjadi hal yang sangat penting bagi seorang guru dalam mengelola pembelajaran. Dengan kompetensi ini, seorang guru dapat merancang, melaksanakan hingga mengevaluasi hasil pembelajaran dengan tepat, sesuai karakteristik siswa dan mata pelajaran yang diampunya. Sehingga keberhasilan belajar dapat dicapai semaksimal

${ }^{3}$ Tim Pengembangan Ilmu Pendidikan FIP UPI. 2007. Ilmu dan Aplikasi Pendidikan Bagian III: Pendidikan Disiplin Ilmu. Bandung: Imperial Bhakti Utama, cet. ke-2, h. 6-12

${ }^{4}$ Husein Syahatah. 2004. Kiat Islami Meraih Prestasi. Jakarta: Gema Insani Press., cet ke-1, h. 62 
mungkin. Kompetensi pedagogik menjadi vital keberadaannya dalam diri seorang guru dalam menjalankan perannya sebagai manajer dan fasilitator pembelajaran siswa. Sehingga peran guru baik secara langsung maupun tidak langsung akan berdampak pada kualitas pembelajaran yang diciptakan, sehingga akan mampu menumbuhkan motivasi belajar siswa dan prestasi belajar yang diraih siswa.

Kenyataan-kenyataan yang ada di lapangan disandingkan dengan teori yang ada, memunculkan beberapa pertanyaan. Bagaimana keadaan kompetensi pedagogik guru? Bagaimana keadaan motivasi belajar dan prestasi belajar siswa? Apakah terdapat hubungan nyata antara kompetensi pedagogik dengan motivasi belajar siswa? Apakah terdapat hubungan nyata antara kompetensi pedagogik dengan prestasi belajar siswa? Berdasarkan kenyataan inilah penulis terdorong melakukan penelitian dengan topik "Hubungan antara Kompetensi Pedagogik Guru Agama dengan Motivasi siswa dan Prestasi Belajar Siswa pada Siswa Kelas VIII SMP PGRI 1 Cibinong".

\section{Permasalahan Penelitian}

Dari berbagai permasalahan tersebut, maka permasalahan penelitian dirumuskan tentang bagaimana keadaan: a) kompetensi pedagogik guru agama di SMP PGRI 1 Cibinong?, b) motivasi belajar siswa kelas VIII SMP PGRI 1 Cibinong?, c) prestasi belajar siswa kelas VIII SMP PGRI 1 Cibinong?, d hubungan antara kompetensi pedagogik guru agama dengan motivasi belajar siswa pada mata pelajaran PAI?, dan e) hubungan antara kompetensi pedagogik guru agama dengan prestasi belajar siswa pada mata pelajaran PAI?

\section{Tujuan Penelitian}

Berdasarkan perumusan masalah tersebut, maka tujuan penelitian yang ingin dicapai adalah untuk mendeskripsikan ten- tang: a) kompetensi pedagogik guru agama di SMP PGRI 1 Cibinong, b) motivasi belajar siswa kelas VIII SMP PGRI 1 Cibinong, c) prestasi belajar siswa kelas VIII SMP PGRI 1 Cibinong, d) hubungan antara kompetensi pedagogik guru agama dengan motivasi belajar siswa pada mata pelajaran PAI, dan e) hubungan antara kompetensi pedagogik guru agama dengan prestasi belajar siswa pada mata pelajaran PAI.

\section{KERANGKA BERPIKIR}

\section{Motivasi Belajar}

Bukan hal yang mudah untuk membangkitkan dan mempertahankan motivasi belajar siswa. Seorang guru hendaknya mengetahui faktor-faktor yang mempengaruhi motivasi belajar siswa. Berikut merupakan 6 faktor yang mempengaruhi motivasi belajar: 1) Cita-cita atau aspirasi siswa, 2) Kemampuan siswa, 3) Kondisi siswa, 4) Kondisi lingkungan siswa, 5) Unsur-unsur dinamis dalam belajar dan pembelajaran, 6) Upaya guru dalam membelajarkan siswa ${ }^{5}$.

Dari faktor-faktor tersebut, pada faktor ke 6 menunjukkan bahwa motivasi belajar siswa juga dipengaruhi oleh sejauh mana guru mampu mengelola pembelajaran secara efektif dengan memperhatikan kemampuan, kondisi siswa dan lingkungan siswa dan unsur-unsur dinamis dalam belajar dan pembelajaran.

\section{Prestasi Belajar}

Sementara itu, prestasi belajar adalah hasil yang dicapai seorang siswa berupa perubahan, penambahan dan peningkatan kualitas perilaku dari ranah kognitif, afektif dan psikomotor yang dicapai melalui aktifitas siswa dalam proses belajar ${ }^{6}$.

${ }^{5}$ Dimyati dan Mudjiono. 2009. Belajar dan Pebelajaran. Jakarta: Rineka Cipta, h. 97-100.

${ }^{6}$ Arlindo Fransisco Marcal. 2006. Pengaruh Motivasi Belajar dan Disiplin Diri terhadap Prestasi Belajar Karya Siswa Timor-Leste di Jakarta. http:/ /isjd.lipi.go- 
Definisi lain menyebutkan bahwa prestasi belajar adalah suatu bukti keberhasilan belajar atau kemampuan seseorang dalam melakukan kegiatan belajar sesuai dengan bobot yang dicapainya ${ }^{7}$. Prestasi belajar tidak muncul dengan sendirinya melainkan melewati suatu proses tertentu berupa proses belajar mengajar yang dipimpin oleh guru. Prestasi belajar dengan demikian merupakan gambaran dari mutu pembelajaran yang telah dilaksanakan seorang guru. Menurut Syah ${ }^{8}$, Faktor kompetensi guru secara umum yang berpengaruh terhadap prestasi belajar adalah faktor eksternal, sedangkan menurut Djamarah ${ }^{9}$ dan Purwanto ${ }^{10}$ yang berpengaruh adalah faktor instrumental.

Penelitian yang dilakukan oleh Heyneman dan Loxley ${ }^{11}$ menyatakan bahwa mutu pembelajaran yang ditunjukkan oleh prestasi belajar siswa sepertiganya ditentukan oleh guru. Sedangkan menurut Widioko, ${ }_{12}^{12}$ guru-guru mempunyai pengaruh yang paling penting terhadap kemajuan murid, bahkan lebih penting daripada status sosial ekonomi dan lokasi sekolah.

.id/-admin/jurnal/51706119, diakses 19 November 2011

${ }^{7}$ WS Winkle dalam Ghullam Hamdu dan Lisa Agustina. 2011. Pengaruh Motivasi Belajar Siswa terhadap Prestasi Belajar IPA di Sekolah Dasar (Studi Kasus terhadap Siswa Kelas IV SDN Tarumanagara Kecamatan Tawang, Kota Tasikmalaya. http://jurnal.upi.edu/, diakses 19 November 2011

${ }^{8}$ Muhibbin Syah. 2010. Psikolologi Belajar. Jakarta: Rajawali Press, h. 154.

${ }^{9}$ Syaiful Bahri Djamarah. 2011. Psikologi Belajar. Jakarta: Rineka Cipta, h. 176-202.

${ }^{10}$ Ngalim Purwanto. 2010. Psikologi Pendidikan. Bandung: Rosdakarya, h. 106.

${ }^{11}$ Eko Putro Widoyoko. 2011. Analisis Pengaruh Kinerja Guru terhadap Motivasi Belajar Siswa. http:/ / www.umpwr.ac.id.

${ }^{12}$ Daniel Suryadarma, et.al. 2005. Penentu Kinerja Murid Sekolah Dasar di Indonesia: Peranan Guru dan Sekolah. Jakarta: Lembaga Penelitian Smeru, h. 8.
Penelitian lainnya di antaranya oleh Steadly, et. al, ${ }^{13}$ Hughes and $\mathrm{Kwok}^{14}$, dan Lastantri ${ }^{15}$ yang lebih khusus mengkaji kompetensi pedagogik selanjutnya menyebutkan bahwa kompetensi pedagogik berpengaruh terhadap prestasi belajar siswa.

\section{Kemampuan Pedagogik}

Menurut Raharjo ${ }^{16}$ dan Steedly et. $a{ }^{17}$, guru dapat dikatakan sebagai agen perubahan di dunia pendidikan khususnya di kelas. Sebagai "agen" yang mengubah kognitif, afektif, maupun psikomotorik peserta didik (siswa), maka interaksi antara guru dan peserta didik yang diwujudkan dengan kegiatan pembelajaran yang efektif menjadi sesuatu keharusan agar pelaksanaan "transfer of knowledge" dapat berjalan dengan baik. Untuk dapat mewujudkan kegiatan pembelajaran yang efektif tentu akan sangat dibutuhkan kemampuan mengelola pembelajaran sesuai dengan perkembangan dan karakteristik peserta didik, yakni kompetensi pedagogik.

${ }^{13}$ Kathlyn M Steedly, Amanda Schwartz, Michael Levin and Stephen D Luke. 2008. Social Skills and Academic Achievement: Evidence for Education. http:/ / nichcy.org/research/ee/social-skills, diakses 15 November 2011

${ }^{14}$ Jan Hughes and Oi-man Kwok. 2006. Influence of Student-Teacher and Parent-Teacher Relationships on Lower Achieving Readers: Engagement and Achievement in the Primary Grades. http:/ / www. ncbi.nlm.nih.gov/pmc/articles/PMC2140005/, di akses 15 November 2011

${ }^{15}$ Fena Desi Lastantri. 2010. Pengaruh Kompetensi Guru (Kompetensi Pedagogik, Profesional, Kepribadian, dan Sosial) Terhadap Prestasi Belajar di SMK Program Keahlian Akuntansi Se-Kabupaten Cilacap. http:/ / fe.unnes.ac.id., diakses 15 November 2011

${ }^{16}$ Tri Weda Raharjo. 2008. Efektifitas Komunikasi dalam Pelaksanaan Proses Belajar Mengajar pada SMK Negeri di Kota Kediri, www.balitbang.depkominfo. go.id,, diakses 19 November 2011

${ }^{17}$ Kathlyn M Steedly, Amanda Schwartz, Michael Levin and Stephen D Luke. 2008, Social Skills and Academic Achievement: Evidence for Education. http://nichcy.org/research/ee/social-skills, diakses 15 November 2011 
Kompetensi pedagogik adalah kemampuan mengelola pembelajaran peserta $\operatorname{didik}^{18}$. Lebih rinci, dalam Peraturan Pemerintah No. 74 Tahun 2008 tentang Guru pasal 3, kompetensi pedagogik diartikan sebagai kemampuan guru dalam mengelola pembelajaran peserta didik yang meliputi pemahaman akan wawasan atau landasan kependidikan, peserta didik, perancangan dan pelaksanaan pembelajaran, evaluasi hasil belajar dan pengembangan peserta didik untuk mengaktualisasikan berbagai potensi yang dimilikinya ${ }^{19}$. Dalam lampiran Peraturan Menteri Pendidikan Nasional No. 16 Tahun 2007, disebutkan bahwa ada 10 kemampuan inti dari kompetensi pedagogik guru, yaitu: 1) Menguasai karakteristik peserta didik dari aspek fisik, moral, sosial, kultural, emosional, dan intelektual, 2) Menguasai teori belajar dan prinsip-prinsip pembelajaran yang mendidik, 3) Mengembangkan kurikulum terkait dengan mata pelajaran yang diampu, 4) Menyelenggarakan pembelajaran yang mendidik, 5) Memanfaatkan teknologi informasi dan untuk komunikasi untuk kepentingan pembelajaran, 6) Memfasilitasi pengembangan potensi peserta didik untuk mengaktualisasikan berbagai potensi yang dimiliki, 7) Berkomunikasi efektif, empatik dan santun dengan peserta didik, 8) Menyelenggarakan penilaian dan evaluasi proses dan hasil belajar penilaian proses dan hasil belajar; menganalisis hasil penilaian dan hasil belajar; melakukan evaluasi proses dan hasil belajar, 9 ) Memanfaatkan hasil penilaian dan evaluasi untuk kepentingan pembelajaran, 10) Melakukan tindakan reflektif untuk peningkatan kualitas pembelajaran yang diampu ${ }^{20}$.

Subkompetensi pedagogik di atas akan memberikan dampak positif pengoptimalan peran guru dalam proses pembelajaran,

${ }^{18}$ Himpunan Peraturan Perundang-undangan: Undang-Undang Guru dan Dosen. 2010. Bandung: Fokusmedia, h. 48.

19 Ibid., h. 66.

20 Ibid., h. 162-166. di antaranya guru sebagai sumber belajar, demonstrator, pembimbing, fasilitator, manajer, motivator dan evaluator ${ }^{21}$. Sebagai manajer dan fasilator, dukungan kompetensi pedagogik, akan dapat membuat seorang guru mengelola dan mengkondisikan kelas secara maksimal. Mulai dari merancang pembelajaran, melaksanakan hingga melakukan evaluasi pembelajaran sesuai dengan perkembangan dan karakteristik siswa, serta karakteristik mata pelajaran yang diampunya. Jika pengelolaan pembelajaran telah dilakukan dengan optimal maka pembelajaran yang berkualitas akan tercipta dan berakhir pada pencapaian hasil belajar (prestasi belajar) siswa secara maksimal. Salah satu hasil penelitian yang dilakukan oleh Heyneman dan Loxley menyatakan bahwa mutu pembelajaran yang ditunjukkan oleh prestasi belajar siswa sepertiganya ditentukan oleh guru ${ }^{22}$.

Kompetensi pedagogik juga mutlak diperlukan seorang guru untuk menjalankan perannya sebagai motivator pembelajaran. Sebagai motivator, seorang guru harus dapat membangkitkan motivasi belajar siswa, karena motivasi merupakan aspek dinamis yang sangat penting. Sering terjadi siswa yang kurang berprestasi bukan karena rendahnya kemampuan yang dimilikinya, melainkan karena tidak adanya motivasi untuk belajar sehingga tidak berusaha untuk memaksimalkan kemampuan yang dimilikinya ${ }^{23}$. Begitu pentingnya pembangkitan motivasi belajar siswa ini karena akan berdampak pada perilaku belajar yang diharapkan. Sebagaimana diketahui bahwa motivasi merupakan keseluruhan daya penggerak di dalam diri siswa yang menimbulkan kegiatan belajar dan memberikan arah pada kegiatan belajar, sehingga tujuan yang dikehendaki oleh subjek belajar itu

${ }^{21}$ Wina Sanjaya. 2008. Strategi Pembelajaran. Jakarta: Kencana, h. 21-31.

${ }^{22}$ Eko Putro Widoyoko. 2011. Analisis Pengaruh Kinerja Guru terhadap Motivasi Belajar Siswa. http://www.umpwr.ac.id

${ }^{23}$ Wina Sanjaya, Op. cit., h. 28. 
dapat tercapai ${ }^{24}$. Serupa dengan pendapat di atas, bahwa motivasi belajar juga akan membuat siswa cenderung melakukan kegiatan belajar yang didorong oleh hasrat untuk mencapai prestasi atau hasil belajar sebaik mungkin ${ }^{25}$. Beberapa hasil penelitian juga menemukan fakta bahwa kompetensi guru berpengaruh terhadap motivasi belajar siswa ${ }^{26}$. Demikian juga dengan Indarto menemukan kompetensi pedagogik berpengaruh terhadap motivasi belajar siswa ${ }^{27}$.

Guru dengan demikian menjadi faktor determinan yang memberi pengaruh positif terhadap kualitas sebuah pembelajaran ${ }^{28}$. Karenanya ia harus didukung kompetensi yang memadai dalam rangka mengelola proses pembelajaran-satu di antaranya kompetensi pedagogik. Dengan pengetahuan dan keterampilan ini, guru akan mampu menjalankan perannya sebagai manajer dan motivator pembelajaran secara optimal. Hingga ia akan mampu menciptakan pembelajaran berkualitas, pembelajaran berkualitas akan membantu menumbuhkan motivasi belajar para siswa, dan akhirnya berujung pada peningkatan prestasi belajar siswa pada mata pelajaran PAI.

Berdasarkan pada kerangka pemikiran di atas, maka dibuatlah model penelitian sebagai berikut:

${ }^{24}$ Sardiman A M, 1996. Interaksi dan Motivasi Belajar Mengajar. Jakarta: Rajawali Pres., h. 75.

${ }^{25}$ Clayton dalam Ghullam Hamdu dan Lisa Agustina. 2011. Pengaruh Motivasi Belajar Siswa terhadap Prestasi Belajar IPA di Sekolah Dasar (Studi Kasus terhadap Siswa Kelas IV SDN Tarumanagara Kecamatan Tawang, Kota Tasikmalaya. http://jurnal.upi.edu, diakses 19 November 2011.

${ }^{26}$ Dimyati dan Mudjiono. 2009. Belajar dan Pembelajaran. Jakarta: Rineka Cipta., h. 97-100.

${ }^{27}$ Ardzy Panggayuh Indarto. 2011. Pengaruh Kompetensi Pedagogik, Kepribadian, Profesional, Dan Sosial Guru Praktikan Terhadap Motivasi Belajar Siswa SMK Negeri 1 Singosari Kabupaten Malang. http://karya-ilmiah.um.ac.id, diakses 20 Desember 2011.

${ }^{28}$ Abuddin Nata. 2010. Manajemen Pendidikan: Mengatasi Kelemahan Pendidikan Islam di Indonesia. Jakarta: Kencana, cet ke-4, h. 161

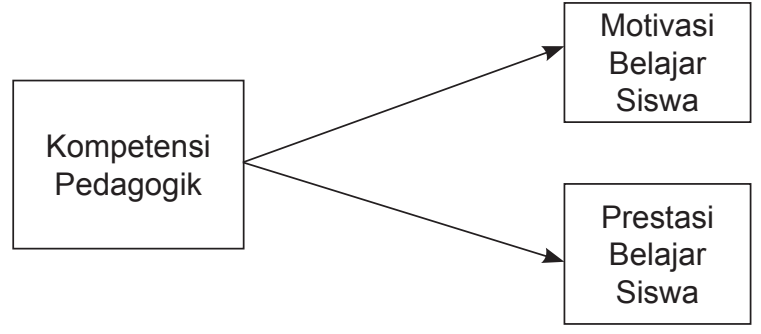

Gambar 1. Model Penelitian

\section{Hipotesis Penelitian}

Berdasarkan kerangka pemikiran dan model penelitian tersebut, maka disusun hipotesis sebagai berikut: a) terdapat hubungan yang nyata antara kompetensi pedagogik guru agama dengan motivasi belajar siswa SMP PGRI 1 Cibinong, dan b) terdapat hubungan yang nyata antara kompetensi pedagogik guru agama dengan prestasi belajar PAI siswa SMP PGRI 1 Cibinong.

\section{METODE PENELITIAN}

Penelitian ini menggunakan metode deskriptif analitik dengan teknik survai yang berlangsung pada bulan Mei sampai Juni 2012 di SMP PGRI 1 Cibinong, Kabupaten Bogor. Populasi penelitian ini adalah siswa kelas VIII SMP PGRI 1 Cibinong, Kabupaten Bogor yang semuanya berjumlah 426 orang. Sampel diambil sebanyak $20 \%$ dari populasi sehingga terdapat 86 orang dengan menggunakan teknik cluster proportional sampling.

Untuk menguji berbagai hipotesis yang dirumuskan dalam penelitian ini akan dianalisis dengan menggunakan analisis Tau-b Kendall (Agresti dan Barbara Finlay 1986). Dengan mempertimbangkan kerumitan penghitungan, analisis data dilakukan dengan menggunakan bantuan Program PASW Versi 18. 


\section{HASIL DAN PEMBAHASAN}

\section{Kompetensi Pedagogik Guru Agama}

Dilihat dari Tabel 1, kompetensi pedagogik guru agama SMP PGRI 1 Cibinong terkategori sedang cenderung ke tinggi pada semua sub variabelnya, baik pada kompetensi pedagogik guru agama total $(60,5 \%)$ maupun kompetensi pedagogik guru agama parsialnya (di atas 51,2\% dengan sub variable kemampuan menyelenggarakan penilaian dan evaluasi proses dan hasil belajar sebagai kompetensi guru yang paling rendah).

Sub variabel kemampuan menyelenggarakan pembelajaran yang mendidik dipersepsikan siswa sebagai suatu kompetensi guru yang tertinggi (59,3\%). Dengan demikian siswa merasa bahwa guru agama telah memberikan pengajaran yang sesuai dengan karakteristik, minat dan kebutuhannya serta mengarahkan tujuan pembelajaran pada perubahan perilaku yang diharapkan.

Tabel 1. Kompetensi Pedagogik Guru Agama SMP PGRI 1 Cibinong

\begin{tabular}{|c|c|c|c|c|c|}
\hline No & Variabel & Kategori & $\begin{array}{c}\text { Rentang } \\
\text { Skor }\end{array}$ & Jumlah & $\%$ \\
\hline \multirow{3}{*}{1} & \multirow{3}{*}{$\begin{array}{l}\text { Penguasaan teori } \\
\text { belajar dan prinsip- } \\
\text { prinsip mendidik }\left(X_{1}\right)\end{array}$} & Rendah & $18-41$ & 7 & 8,1 \\
\hline & & Sedang & $42-66$ & 49 & 56,9 \\
\hline & & Tinggi & $67-90$ & 30 & 35 \\
\hline \multirow{3}{*}{2} & \multirow{3}{*}{$\begin{array}{l}\text { Implementasi } \\
\text { pengembangan kurikulum } \\
\text { PAI }\left(X_{2}\right)\end{array}$} & Rendah & $06-13$ & 4 & 4,6 \\
\hline & & Sedang & $14-22$ & 49 & 57 \\
\hline & & Ting & $23-30$ & 33 & 38,4 \\
\hline \multirow{3}{*}{3} & \multirow{3}{*}{$\begin{array}{l}\text { Kemampuan } \\
\text { menyelenggarakan } \\
\text { pembelajaran yang } \\
\text { mendidik }\left(X_{3}\right)\end{array}$} & Rendah & $24-55$ & 5 & 58 \\
\hline & & Sedang & $56-88$ & 51 & 59,3 \\
\hline & & Tinggi & $89-120$ & 30 & 34,9 \\
\hline \multirow{3}{*}{4} & \multirow{3}{*}{$\begin{array}{l}\text { Kemampuan memfasilitasi } \\
\text { pengembangan potensi } \\
\text { peserta didik }\left(X_{4}\right)\end{array}$} & Rendah & $17-39$ & 5 & 5,8 \\
\hline & & Sedang & $40-62$ & 50 & 58,2 \\
\hline & & Tinggi & $63-85$ & 31 & 36 \\
\hline \multirow{3}{*}{5} & \multirow{3}{*}{$\begin{array}{l}\text { Kemampuan } \\
\text { berkomunikasi efektif, } \\
\text { empatik dan santun } \\
\text { dengan peserta didik }\left(X_{5}\right)\end{array}$} & Rendah & $10-23$ & 10 & 11,6 \\
\hline & & Sedang & $24-36$ & 46 & 53,5 \\
\hline & & Tinggi & $37-50$ & 30 & 34,9 \\
\hline \multirow{3}{*}{6} & \multirow{3}{*}{$\begin{array}{l}\text { Kemampuan menyeleng- } \\
\text { garakan penilaian dan } \\
\text { evaluasi proses dan hasil } \\
\text { belajar }\left(X_{6}\right)\end{array}$} & & $08-18$ & 0 & 5,8 \\
\hline & & Sedang & $19-29$ & 44 & 51,2 \\
\hline & & Tinggi & $30-40$ & 37 & 43 \\
\hline \multirow{3}{*}{7} & Kompetensi pedagogik $(X)$ & Rendah & 83-193 & 3 & 3,5 \\
\hline & (Jumlah skor) & Sedang & 194-304 & 52 & 60,5 \\
\hline & Jumlah & Tinggi & $305-415$ & 31 & 36 \\
\hline
\end{tabular}

Sumber: Data diolah dari hasil survai (2012)
Sedangkan sub variabel kemampuan menyelenggarakan penilaian dan evaluasi proses dan hasil belajar telah dipersepsikan sebagai kompetensi guru yang paling rendah $(51,2 \%)$. Siswa merasa bahwa guru agama masih belum sepenuhnya objektif dalam menilai, siswa juga menilai bahwa guru kurang menilai dari semua unsur penilaian sehingga dapat mengurangi rasa keadilan menilai.

\section{Motivasi Belajar Siswa}

Motivasi belajar siswa (sebagaimana tabel 2) secara umum berada pada kategori tinggi, baik pada motivasi belajar total $(61,6 \%)$ maupun motivasi parsialnya (di atas $57 \%$ ), termasuk pada sub variabel motivasi pengaruh yang menunjukkan sedang cenderung ke tinggi.

Tabel 2. Motivasi Belajar Siswa Kelas VIII SMP PGRI 1 Cibinong

\begin{tabular}{|c|l|l|c|c|c|}
\hline No & \multicolumn{1}{|c|}{ Variabel } & Kategori & Rentang skor & Jumlah & $\%$ \\
\hline \multirow{3}{*}{1} & Dorongan & Rendah & $07-16$ & 1 & 1,2 \\
& berprestasi $\left(Y_{1.1}\right)$ & Sedang & $17-25$ & 12 & 14 \\
& & Tinggi & $26-35$ & 73 & 84,8 \\
\hline \multirow{3}{*}{2} & Dorongan & Rendah & $07-16$ & 2 & 2,3 \\
& berafiliasi $\left(Y_{1.2}\right)$ & Sedang & $17-25$ & 35 & 40,7 \\
& & Tinggi & $26-35$ & 49 & 57 \\
\hline \multirow{3}{*}{3} & Dorongan & Rendah & $07-16$ & 3 & 3,5 \\
& pengaruh $\left(\mathrm{Y}_{1.3}\right)$ & Sedang & $17-25$ & 44 & 51,2 \\
& & Tinggi & $26-35$ & 39 & 45,3 \\
\hline \multirow{3}{*}{4} & \multirow{2}{*}{ Motivasi belajar } & Rendah & $21-48$ & 0 & 0 \\
& Siswa $\left(\mathrm{Y}_{1}\right)$ & Sedang & $49-77$ & 33 & 38,4 \\
& & Tinggi & $78-105$ & 53 & 61,6 \\
\hline
\end{tabular}

Sumber: Data diolah dari hasil survai (2012)

Tingginya motivasi responden tersebut berasal dari adanya keinginan untuk mendapatkan penghargaan baik dari guru, teman maupun sekolah. Adapun motivasi pengaruh siswa yang sedang cenderung ke tinggi menunjukkan bahwa siswa tidak banyak termotivasi untuk memperoleh pengakuan banyak temannya di sekolah. Terdapat dugaan terkait dengan semakin merebaknya jejaring sosial menjadikan siswa memiliki banyak teman di dunia maya tersebut sehingga tidak terlalu penting untuk mendapatkan pengaruh dari teman di dunia nyata. 


\section{Prestasi Belajar Siswa}

Sebagaimana terlihat pada Tabel 3 . Setengah responden berprestasi belajar dengan kategori tinggi (51,2\%). Lebih-lebih dalam prestasi formatif dan prestasi sumatif sebanyak $3 / 4$ responden memiliki prestasi belajar tinggi (prestasi formatif $78 \%$ dan prestasi sumatif 75,6\%). Penilaian terbesar hanya pada aspek afektif (akhlak) yang tidak sebanding dengan penilaian pada aspek kognitif maupun psikomotor.

Tabel 3. Prestasi Belajar Siswa Kelas VIII SMP PGRI 1 Cibinong

\begin{tabular}{|c|c|c|c|c|c|}
\hline No & Variabel & Kategori & $\begin{array}{l}\text { Rentang } \\
\text { skor }\end{array}$ & Jumlah & $\%$ \\
\hline 1 & Prestasi formatif $\left(\mathrm{Y}_{2.1}\right)$ & $\begin{array}{c}\text { Rendah } \\
\text { Sedang } \\
\text { Tinggi }\end{array}$ & $\begin{array}{l}117-136 \\
137-156 \\
157-176 \\
\end{array}$ & $\begin{array}{c}5 \\
14 \\
67 \\
\end{array}$ & $\begin{array}{c}5,8 \\
16,2 \\
78\end{array}$ \\
\hline 2 & $\begin{array}{l}\text { Prestasi sub sumatif } \\
\left(\mathrm{Y}_{2.1}\right)\end{array}$ & $\begin{array}{c}\text { Rendah } \\
\text { Sedang } \\
\text { Tinggi }\end{array}$ & $\begin{array}{l}44-60 \\
61-76 \\
77-93\end{array}$ & $\begin{array}{l}18 \\
41 \\
27\end{array}$ & $\begin{array}{c}21 \\
47,6 \\
31,4\end{array}$ \\
\hline 3 & Prestasi sumatif $\left(\mathrm{Y}_{2.1}\right)$ & $\begin{array}{c}\text { Rendah } \\
\text { Sedang } \\
\text { Tinggi }\end{array}$ & $\begin{array}{l}50-63 \\
64-76 \\
77-90\end{array}$ & $\begin{array}{c}21 \\
0 \\
65\end{array}$ & $\begin{array}{c}24,4 \\
0 \\
75,6\end{array}$ \\
\hline 4 & $\begin{array}{l}\text { Prestasi belajar siswa } \\
\left(Y_{2}\right)\end{array}$ & $\begin{array}{c}\text { Rendah } \\
\text { Sedang } \\
\text { Tinggi }\end{array}$ & $\begin{array}{l}229-265 \\
266-301 \\
302-338\end{array}$ & $\begin{array}{c}3 \\
39 \\
44\end{array}$ & $\begin{array}{r}3,5 \\
45,3 \\
51,2\end{array}$ \\
\hline
\end{tabular}

Sumber: Data diolah dari hasil survai (2012)

Tingginya prestasi belajar siswa terutama dalam prestasi formatif dan prestasi sumatif yang sedikit berbeda dengan prestasi sub sumatif. Prestasi sub sumatif merupakan penilaian yang sesungguhnya, karena tidak dipengaruhi oleh tuntutan pemenuhan nilai KKM serta subjektifitas guru penilai, sehingga pada prestasi sub sumatif menunjukan kategori sedang.

\section{Hubungan antara Kompetensi Pedagogik Guru dengan Motivasi Belajar Siswa}

Hasil uji koefisien korelasi Tau-b Kendall sebagaimana tabel 4 menunjukkan bahwa sebagian besar variabel kompetensi pedagogik guru $(X)$ yang meliputi sub variabel penguasaan teori belajar dan prinsip-prinsip mendidik $\left(X_{1}\right)$, kemampuan menyelenggarakan pembelajaran yang mendidik $\left(X_{3}\right)$, kemampuan memfasilitasi pengembangan potensi peserta didik $\left(X_{4}\right)$, kemampuan berkomunikasi efektif, empatik dan santun dengan peserta didik $\left(X_{5}\right)$, dan kemampuan menyelenggarakan penilaian dan evaluasi proses dan hasil belajar $\left(X_{6}\right)$ berhubungan nyata dengan variabel motivasi belajar siswa $\left(Y_{1}\right)$. Hanya satu sub variabel, yaitu implementasi pengembangan kurikulum PAI $\left(X_{2}\right)$ yang tidak berhubungan nyata positif dengan motivasi belajar siswa $\left(\mathrm{Y}_{1}\right)$. Adapun nilai korelasi semua variabel dapat dilihat pada tabel 4 .

Hubungan secara nyata positif antara sebagian besar variabel kompetensi pedagogik guru $(X)$ dengan motivasi belajar siswa $\left(Y_{1}\right)$ disebabkan kondisi kompetensi pedagogik guru rata-rata terkategori sedang cenderung ke tinggi. Dengan kompetensi pedagogik yang tinggi tersebut akan memberikan dampak positif pengoptimalan peran guru dalam proses pembelajaran. Kompetensi pedagogik bermakna mulai berperannya guru sebagai motivator pembelajaran. Sebagai motivator, seorang guru harus dapat membangkitkan motivasi belajar siswa, karena motivasi merupakan aspek dinamis yang sangat penting. Sering terjadi siswa yang kurang berprestasi bukan karena rendahnya kemampuan yang dimilikinya, melainkan karena tidak adanya motivasi untuk belajar sehingga tidak berusaha untuk memaksimalkan kemampuan yang dimilikinya ${ }^{29}$. Begitu pentingnya pembangkitan motivasi belajar siswa ini karena akan berdampak pada perilaku belajar yang diharapkan. Itulah sebabnya sebagian besar variabel kompetensi pedagogik guru $(X)$ berhubungan nyata positif dengan motivasi belajar siswa $\left(\mathrm{Y}_{1}\right)$.

${ }^{29}$ Sanjaya, Loc. Cit., h. 28 
Tabel 4. Hubungan antara Kompetensi Pedagogik Guru dengan Motivasi Belajar Siswa

\begin{tabular}{|c|l|c|c|c|c|}
\hline No & \multicolumn{1}{|c|}{ Variabel } & $\begin{array}{c}\text { Dorongan } \\
\text { Berpres- } \\
\text { tasi }\left(Y_{1,1}\right)\end{array}$ & $\begin{array}{c}\text { Dorongan } \\
\text { Berafiliasi } \\
\left(Y_{1,2}\right)\end{array}$ & $\begin{array}{c}\text { Dorongan } \\
\text { Pengaruh } \\
\left(Y_{1,3}\right)\end{array}$ & $\begin{array}{c}\text { Motivasi } \\
\text { Kerja } \\
\left(Y_{1}\right)\end{array}$ \\
\hline 1 & $\begin{array}{l}\text { Penguasaan teori be- } \\
\text { lajar dan prinsip-prinsip } \\
\text { mendidik }\left(X_{1}\right)\end{array}$ & $\begin{array}{c}0,142 \\
(0,175)\end{array}$ & $\begin{array}{c}0,168 \\
(0,106)\end{array}$ & $\begin{array}{c}0,065 \\
(0,528)\end{array}$ & $\begin{array}{c}0,216^{*} \\
(0,040)\end{array}$ \\
\hline 3 & $\begin{array}{l}\text { Implementasi } \\
\text { pengembangan } \\
\text { kurikulum PAl }\left(X_{2}\right)\end{array}$ & $\begin{array}{c}0,068 \\
(0,520)\end{array}$ & $\begin{array}{c}0,020 \\
(0,850)\end{array}$ & $\begin{array}{c}-0,102 \\
(0,330)\end{array}$ & $\begin{array}{c}0,027 \\
(0,799)\end{array}$ \\
\hline 4 & $\begin{array}{l}\text { Kemampuan } \\
\text { menyelenggarakan } \\
\text { pembelajaran yang } \\
\text { mendidik }\left(X_{3}\right)\end{array}$ & $\begin{array}{c}0,062 \\
(0,554)\end{array}$ & $\begin{array}{l}0,233^{*} \\
(0,026)\end{array}$ & $\begin{array}{c}0,370^{* *} \\
(0,000)\end{array}$ & $\begin{array}{c}0,364^{* *} \\
(0,001)\end{array}$ \\
\hline $\begin{array}{l}\text { Kemampuan } \\
\text { pengembangan potensi } \\
\text { peserta didik }\left(X_{4}\right)\end{array}$ & $\begin{array}{c}0,161 \\
(0,128)\end{array}$ & $\begin{array}{c}0,227^{*} \\
(0,030)\end{array}$ & $\begin{array}{c}0,425^{* *} \\
(0,000)\end{array}$ & $\begin{array}{c}0,466^{* *} \\
(0,000)\end{array}$ \\
\hline 5 & $\begin{array}{l}\text { Kemampuan } \\
\text { berkmunikasi efektif, } \\
\text { empatik dan santun } \\
\text { dengan peserta didik } \\
\left(X_{5}\right)\end{array}$ & $\begin{array}{c}0,220^{*} \\
(0,034)\end{array}$ & $\begin{array}{c}0,121 \\
(0,241)\end{array}$ & $\begin{array}{c}0,381^{* *} \\
(0,000)\end{array}$ & $\begin{array}{c}0,436^{* *} \\
(0,000)\end{array}$ \\
\hline 6 & $\begin{array}{l}\text { Kemampuan } \\
\text { menyelenggarakan } \\
\text { penilaian dan evaluasi } \\
\text { proses dan hasil belajar } \\
\left(X_{6}\right)\end{array}$ & $\begin{array}{c}0,144 \\
(0,173)\end{array}$ & $\begin{array}{l}0,222^{*} \\
(0,034)\end{array}$ & $\begin{array}{c}0,188 \\
(0,071)\end{array}$ & $\begin{array}{l}0,264^{*} \\
(0,013)\end{array}$ \\
\hline 7 & $\begin{array}{l}\text { Kompetensi pedagogik } \\
(X)\end{array}$ & $\begin{array}{l}0,211^{*} \\
(0,047)\end{array}$ & $\begin{array}{l}0,307^{* *} \\
(0,004)\end{array}$ & $\begin{array}{l}0,325^{* *} \\
(0,002)\end{array}$ & $\begin{array}{l}0,389^{* *} \\
(0,000)\end{array}$ \\
\hline
\end{tabular}

Sumber:

\section{Keterangan:}

Data diolah dari hasil survai (2012)

* Signifikan pada taraf kepercayaan 95\%

** Signifikan pada taraf kepercayaan 99\%

Hanya satu sub variabel kompetensi pedagogik yang tidak berhubungan nyata positif dengan motivasi belajar siswa $\left(Y_{1}\right)$, yaitu implementasi pengembangan kurikulum PAI.

1. Meski keadaan implementasi pengembangan kurikulum PAI berada pada kategori sedang cenderung ke tinggi, namun pada kondisi sebenarnya, seperti penggunaan buku pembelajaran yang terkini dan terbaru hanya sebagai buku pelengkap saja, namun cenderung untuk tidak dijadikan pegangan utama dalam proses pembelajaran sehari-hari yang lebih banyak dipercayakan pada Lembar Kerja Siswa (LKS) saja.

2. Dari keadaan siswa, hanya sebagian yang mempergunakan buku pelajaran yang terkini dan terbaru, namun dalam proses pembelajaran banyak di antara siswa yang memiliki buku pelajaran
PAI yang terkini dan terbaru tersebut tidak menggunakannya secara sungguh-sungguh dengan alasan ketinggalan atau tidak terbawa.

Dengan keadaan dari sisi guru maupun siswa seperti tersebut di atas, menjadikan implemantasi kurikulum secara praktek mengalami hambatan dalam meningkatkan motivasi belajar siswa. Hal inilah yang menyebabkan motivasi belajar siswa tidak meningkat.

\section{Hubungan antara Kompetensi Pedagogik Guru dengan Prestasi Belajar Siswa}

Hasil uji korelasi Tau-b Kendall sebagaimana tabel 5 menunjukkan bahwa kompetensi pedagogik guru (X) tidak berhubungan secara nyata positif dengan prestasi belajar siswa secara umum $\left(\mathrm{Y}_{2}\right)$. Namun berhubungan nyata positif dengan sub variabel prestasi belajar yaitu prestasi formatif $\left(\mathrm{Y}_{2.1}\right)$.

Tabel 5. Hubungan antara Kompetensi Pedagogik Guru dengan Prestasi Belajar Siswa

\begin{tabular}{|c|c|c|c|c|c|}
\hline No & Variabel & $\begin{array}{l}\text { Prestasi } \\
\text { Formatif } \\
\text { (Y2.1) }\end{array}$ & $\begin{array}{l}\text { Prestasi } \\
\text { Subsu- } \\
\text { matif } \\
\text { (Y2.2) }\end{array}$ & $\begin{array}{l}\text { Prestasi } \\
\text { Sumatif } \\
\text { (Y2.3) }\end{array}$ & $\begin{array}{l}\text { Prestasi } \\
\text { Belajar } \\
\text { (Y1) }\end{array}$ \\
\hline 1 & $\begin{array}{l}\text { Penguasaan teori belajar } \\
\text { dan prinsip-prinsip men- } \\
\text { didik (X1) }\end{array}$ & $\begin{array}{l}0,277^{* *} \\
(0,007)\end{array}$ & $\begin{array}{c}0,101 \\
(0,310)\end{array}$ & $\begin{array}{c}-0,009 \\
(0,935)\end{array}$ & $\begin{array}{c}0,102 \\
(0,324)\end{array}$ \\
\hline 2 & $\begin{array}{l}\text { Implementasi pengem- } \\
\text { bangan kurikulum PAl } \\
(\mathrm{X} 2)\end{array}$ & $\begin{array}{c}0,177 \\
(0,088)\end{array}$ & $\begin{array}{c}0,077 \\
(0,443)\end{array}$ & $\begin{array}{c}-0,047 \\
(0,656)\end{array}$ & $\begin{array}{c}0,158 \\
(0,132)\end{array}$ \\
\hline 3 & $\begin{array}{l}\text { Kemampuan menyeleng- } \\
\text { garakan pembelajaran } \\
\text { yang mendidik (X3) }\end{array}$ & $\begin{array}{l}0,268^{* *} \\
(0,010)\end{array}$ & $\begin{array}{c}-0,046 \\
(0,650)\end{array}$ & $\begin{array}{c}-0,194 \\
(0,067)\end{array}$ & $\begin{array}{c}-0,062 \\
(0,549)\end{array}$ \\
\hline 4 & $\begin{array}{l}\text { Kemampuan memfa- } \\
\text { silitasi pengembangan } \\
\text { potensi peserta didik } \\
\text { (X4) }\end{array}$ & $\begin{array}{l}0,292^{* *} \\
(0,005)\end{array}$ & $\begin{array}{c}0,191 \\
(0,057)\end{array}$ & $\begin{array}{c}-0,181 \\
(0,088)\end{array}$ & $\begin{array}{c}0,047 \\
(0,653)\end{array}$ \\
\hline 5 & $\begin{array}{l}\text { Kemampuan berkomuni- } \\
\text { kasi efektif, empatik dan } \\
\text { santun dengan peserta } \\
\text { didik (X5) }\end{array}$ & $\begin{array}{l}0,294^{* *} \\
(0,004)\end{array}$ & $\begin{array}{c}0,162 \\
(0,102)\end{array}$ & $\begin{array}{l}-0,226^{*} \\
(0,030)\end{array}$ & $\begin{array}{c}0,046 \\
(0,656)\end{array}$ \\
\hline 6 & $\begin{array}{l}\text { Kemampuan menyeleng- } \\
\text { garakan penilaian dan } \\
\text { evaluasi proses dan } \\
\text { hasil belajar (X6) } \\
\end{array}$ & $\begin{array}{l}0,258^{*} \\
(0,013)\end{array}$ & $\begin{array}{c}0,096 \\
(0,340)\end{array}$ & $\begin{array}{l}-0,097 \\
(0,357)\end{array}$ & $\begin{array}{c}0,010 \\
(0,927)\end{array}$ \\
\hline 7 & $\begin{array}{l}\text { Kompetensi pedagogik } \\
\text { (X) (Jumlah skor) } \\
\text { Jumlah }\end{array}$ & $\begin{array}{l}0,256^{*} \\
(0,014)\end{array}$ & $\begin{array}{c}-0,014 \\
(0,887)\end{array}$ & $\begin{array}{c}-0,119 \\
(0,264)\end{array}$ & $\begin{array}{c}-0,056 \\
(0,592)\end{array}$ \\
\hline
\end{tabular}

Sumber:

Keterangan:

Data diolah dari hasil survai (2012)

* Signifikan pada taraf kepercayaan 95\%

**Signifikan pada taraf kepercayaan $99 \%$ 
Hubungan secara nyata positif antara variabel kompetensi pedagogik guru $(X)$ dengan prestasi belajar siswa sub variabel prestasi formatif $\left(Y_{2.1}\right)$ disebabkan:

1. Keadaan prestasi formatif siswa berada pada kategori tinggi dan merupakan kategori paling tinggi di antara sub variabel prestasi belajar lainnya,

2. Nilai formatif merupakan nilai harian yang harus memenuhi KKM sehingga guru secara terus menerus melakukan remedial untuk memenuhi tuntutan nilai KKM tersebut. Adanya tuntutan pemenuhan nilai KKM melalui pelaksanaan evaluasi harian menjadikan siswa memiliki banyak aktivitas untuk berlatih dan belajar lebih banyak dan lebih serius dalam kondisi yang senatural mungkin yang berpengaruh terhadap prestasinya secara umum.

Itulah sebabnya terdapat hubungan nyata positif antara variabel kompetensi pedagogik guru $(X)$ dengan prestasi belajar siswa sub variabel prestasi formatif $\left(\mathrm{Y}_{2.1}\right)$.

\section{PENUTUP}

\section{Kesimpulan}

Berdasarkan hasil dan pembahasan yang diuraikan sebelumnya, dapat disimpulkan beberapa hal sebagai berikut:

1. Kompetensi pedagogik guru agama SMP PGRI 1 Cibinong terkategori sedang cenderung ke tinggi pada semua sub variabelnya, baik pada kompetensi pedagogik guru agama total $(60,5 \%)$ maupun kompetensi pedagogik guru agama parsialnya (di atas $51,2 \%$ ). Sub variabel kemampuan menyelenggarakan pembelajaran yang mendidik dipersepsikan siswa sebagai suatu kompetensi guru yang tertinggi (59,3\%). Sedangkan sub variabel kemampuan menyelenggarakan penilaian dan evaluasi proses dan hasil belajar telah di- persepsikan sebagai kompetensi guru yang paling rendah $(51,2 \%)$.

2. Motivasi belajar siswa secara umum berada pada kategori tinggi, baik pada motivasi belajar total $(61,6 \%)$ maupun motivasi parsialnya (di atas 57\%), termasuk pada sub variabel motivasi pengaruh yang menunjukkan sedang cenderung ke tinggi.

3. Setengah responden berprestasi belajar dengan kategori tinggi (51,2\%). Lebih dalam prestasi formatif dan prestasi sumatif sebanyak $3 / 4$ responden memiliki prestasi belajar tinggi (prestasi formatif $78 \%$ dan prestasi sumatif $75,6 \%$ ).

4. Sebagian besar variabel kompetensi pedagogik guru $(X)$ yang meliputi sub variabel penguasaan teori belajar dan prinsip-prinsip mendidik $\left(X_{1}\right)$, kemampuan menyelenggarakan pembelajaran yang mendidik $\left(\mathrm{X}_{3}\right)$, kemampuan memfasilitasi pengembangan potensi peserta didik $\left(\mathrm{X}_{4}\right)$, kemampuan berkomunikasi efektif, empatik dan santun dengan peserta didik $\left(X_{5}\right)$, dan kemampuan menyelenggarakan penilaian dan evaluasi proses dan hasil belajar $\left(X_{6}\right)$ berhubungan nyata dengan variabel motivasi belajar siswa $\left(\mathrm{Y}_{1}\right)$. Hanya satu sub variabel, yaitu implementasi pengembangan kurikulum PAI $\left(\mathrm{X}_{2}\right)$ yang tidak berhubungan nyata positif dengan motivasi belajar siswa $\left(Y_{1}\right)$. Ketidak berhubungan nyata positif antara implementasi pengembangan kurikulum PAI $\left(\mathrm{X}_{2}\right)$ dengan motivasi belajar siswa $\left(Y_{1}\right)$, disebabkan: Meski keadaan implementasi pengembangan kurikulum PAI berada pada kategori sedang cenderung ke tinggi, namun pada kondisi sebenarnya, seperti penggunaan buku pembelajaran yang terkini dan terbaru hanya sebagai buku pelengkap saja, namun cenderung untuk tidak dijadikan pegangan utama dalam proses pembelajaran sehari-hari yang lebih banyak dipercayakan pada Lembar Kerja 
Siswa (LKS) saja. Dari keadaan siswa, hanya sebagian yang mempergunakan buku pelajaran yang terkini dan terba$\mathrm{ru}$, namun dalam proses pembelajaran banyak di antara siswa yang memiliki buku pelajaran PAI yang terkini dan terbaru tersebut tidak menggunakannya secara sungguh-sungguh dengan alasan ketinggalan atau tidak terbawa.

5. Kompetensi pedagogik guru (X) tidak berhubungan secara nyata positif dengan prestasi belajar siswa secara umum $\left(\mathrm{Y}_{2}\right)$. Namun berhubungan nyata positif dengan sub variabel prestasi belajar yaitu prestasi formatif $\left(\mathrm{Y}_{2.1}\right)$. Hubungan secara nyata positif antara variabel kompetensi pedagogik guru (X) dengan prestasi belajar siswa sub variabel prestasi formatif $\left(\mathrm{Y}_{2.1}\right)$ disebabkan: Keadaan prestasi formatif siswa berada pada kategori tinggi dan merupakan kategori paling tinggi di antara sub variabel prestasi belajar lainnya, dan nilai formatif merupakan nilai harian yang harus memenuhi KKM sehingga guru secara terus menerus melakukan remedial untuk memenuhi tuntutan nilai KKM tersebut. Adanya tuntutan pemenuhan nilai KKM melalui pelaksanaan evaluasi harian menjadikan siswa memiliki banyak aktivitas untuk berlatih dan belajar lebih banyak dan lebih serius dalam kondisi yang senatural mungkin yang berpengaruh terhadap prestasinya secara umum.

\section{Saran}

Saran ini ditujukan kepada guru agama di SMP PGRI 1 Cibinong dalam rangka peningkatan kompetensi pedagogik, yaitu:

1. Kompetensi yang perlu ditingkatkan oleh guru agama berkenaan dengan persepsi siswa adalah evaluasi atau penilaian yang seharusnya lebih bersifat objektif. Selain itu juga perlu diperhatikan unsur penilaian yang lebih seimbang antara unsur kognitif, afektif dan psikomotor, meski tidak boleh juga dinafikan perlu dilakukan secara proporsional.

2. Motivasi belajar siswa dalam kategori tinggi sebenarnya merupakan motivasi dari dalam yang pada kenyataannya akan sangat terpengaruh dengan motivasi dari luar, sehingga guru agama perlu memberikan porsi tugas yang agak ekstra untuk ikut memberikan treatmen semacam penugasan tertentu yang dapat lebih menjaga motivasi belajar siswa tidak hanya di sekolah melainkan juga di rumah.

\section{SUMBER BACAAN}

Abuddin Nata. (2010): Manajemen Pendidikan: Mengatasi Kelemahan Pendidikan Islam di Indonesia. Jakarta. Kencana, cet ke-4.

Ardzy Panggayuh Indarto (2011): Pengaruh Kompetensi Pedagogik, Kepribadian, Profesional, Dan Sosial Guru Praktikan Terhadap Motivasi Belajar Siswa SMK Negeri 1 Singosari Kabupaten Malang. http:/ / karya-ilmiah.um.ac.id, diakses 20 Desember 2011.

Arlindo Fransisco Marcal (2006): Pengaruh Motivasi Belajar dan Disiplin Diri terhadap Prestasi Belajar Karya Siswa TimorLeste di Jakarta. http:/ /isjd.lipi.go.id/admin/jurnal/51706119, diakses 19 November 2011

Clayton dalam Ghullam Hamdu dan Lisa Agustina (2011). Pengaruh Motivasi Belajar Siswa terhadap Prestasi Belajar IPA di Sekolah Dasar (Studi Kasus terhadap Siswa Kelas IV SDN Tarumanagara Kecamatan Tawang, Kota Tasikmalaya. http://jurnal.upi.edu, diakses 19 November 2011.

Daniel Suryadarma, et.al. (2005): Penentu Kinerja Murid Sekolah Dasar di Indonesia: Peranan Guru dan Sekolah. Jakarta. Lembaga Penelitian Smeru 
Dimyati dan Mudjiono (2009): Belajar dan Pembelajaran. Jakarta. Rineka Cipta.

Eko Putro Widoyoko (2011): Analisis Pengaruh Kinerja Guru terhadap Motivasi Belajar Siswa. http://www.umpwr.ac.id

Fena Desi Lastantri (2010): Pengaruh Kompetensi Guru (Kompetensi Pedagogik, Profesional, Kepribadian, dan Sosial) Terhadap Prestasi Belajar di SMK Program Keahlian Akuntansi Se-Kabupaten Cilacap. http:/ / fe.unnes.ac.id., diakses 15 November 2011

Himpunan Peraturan Perundang-undangan: Undang-Undang Guru dan Dosen (2010): Bandung. Fokusmedia.

Husein Syahatah (2004): Kiat Islami Meraih Prestasi. Jakarta. Gema Insani Press., cet ke-1.

Jan Hughes and Oi-man Kwok (2006): Influence of Student-Teacher and Parent-Teacher Relationships on Lower Achieving Readers: Engagement and Achievement in the Primary Grades. http://www.ncbi.nlm.nih.gov/pmc/ articles/PMC2140005/, di akses 15 November 2011

Jejen Musfah (2011): Peningkatan Kompetensi Guru: Melalui Pelatihan dan Sumber Belajar Teori dan Praktik. Jakarta. Kencana.

Kathlyn M Steedly, Amanda Schwartz, Michael Levin and Stephen D Luke (2008): Social Skills and Academic Achievement: Evidence for Education. http://nichcy. org/research/ee/social-skills, diakses 15 November 2011

Muhibbin Syah (2010): Psikolologi Belajar. Jakarta. Rajawali Press.

Ngalim Purwanto (2010): Psikologi Pendidikan. Bandung. Rosdakarya.

Sardiman A M (1996): Interaksi dan Motivasi Belajar Mengajar. Jakarta. Rajawali Pres.

Syaiful Bahri Djamarah (2011): Psikologi Belajar. Jakarta. Rineka Cipta.

Tim Pengembangan Ilmu Pendidikan FIP UPI (2007): Ilmu dan Aplikasi Pendidikan Bagian III: Pendidikan Disiplin Ilmu. Bandung, Imperial Bhakti Utama, cet. ke-2.

Tri Weda Raharjo (2008): Efektifitas Komunikasi dalam Pelaksanaan Proses Belajar Mengajar pada SMK Negeri di Kota Kediri, www.balitbang.depkominfo.go.id, diakses 19 November 2011

Wina Sanjaya (2008): Strategi Pembelajaran. Jakarta. Kencana.

WS Winkle dalam Ghullam Hamdu dan Lisa Agustina (2011). Pengaruh Motivasi Belajar Siswa terhadap Prestasi Belajar IPA di Sekolah Dasar (Studi Kasus terhadap Siswa Kelas IV SDN Tarumanagara Kecamatan Tawang, Kota Tasikmalaya. http:/ /jurnal.upi.edu/, diakses 19 November 2011. 